\title{
O PROCESSO DE EXECUÇÃO
}

\section{DAS EMPRESAS ESTATAIS NO BRASIL*}

\author{
Eloi Pethechust ${ }^{* * *}$ \\ Luiz Alberto Blanchet ****
}

\section{RESUMO}

Segundo tradicional entendimento do Supremo Tribunal Federal (STF) as empresas estatais estão sujeitas a dois regimes processuais de execução por quantia certa, sendo o critério de escolha - de um ou de outro - a atividade-fim que a entidade exerce. Assim, caso o ente devedor tenha como função primária a prestação de serviços públicos, terá para si estendidas as prerrogativas processuais da Fazenda Pública, possibilitando a sua execução pelo regime dos precatórios, nos termos dos art. 730 e 731 do Código de Processo Civil (CPC), ao passo que o ente estatal explorador de atividade econômica estará sujeito ao regime de execução comum às empresas privadas, submetendo-se ao disposto no Livro II do CPC. Entretanto, existem no Brasil empresas estatais que exercem ambas as atividades concomitantemente, como é o caso da Empresa Brasileira de Correios e Telégrafos (ECT). Ocorre que o STF, ao analisar qual regime jurídico de execução aplicável à

\section{Recibido: marzo 01 de 2015 - Aceptado: junio 30 de 2015}

* Artículo inédito.

* Especialista em Direito Processual Civil pelo Instituto de Direito Romeu Felipe Bacellar. Mestrando em Direito pela Pontifícia Universidade Católica do Paraná. Conselheiro da Pontifícia Universidade Católica do Paraná (2011/2012). Membro dos grupos de pesquisa "Direito e Economia" e "Regulação Econômica e Atuação Empresarial" da Pontifícia Universidade Católica do Paraná. Membro da Comissão dos Advogados Iniciantes da OAB/ PR. Advogado. Curitiba - PR - Brasil.E-mail: pethechust@hotmail.com.

*:**: Doutor e Mestre em Direito pela Universidade Federal do Paraná. Professor dos cursos de graduação e pós-graduação da Pontifícia Universidade Católica do Paraná. Membro Catedrático da Academia Brasileira de Direito Constitucional (ABDConst). Advogado. Curitiba - PR - Brasil.E-mail: blancht@blancht.adv.br 
ECT, simplesmente classificou a entidade como prestadora de serviço público, razão pela qual lhe foi aplicado o privilégio da impenhorabilidade de bens, rendas e serviços, determinando-se a observância do regime de precatório. Nesse contexto, a presente pesquisa tem por objetivo questionar o posicionamento exarado pelo STF no tocante ao regime jurídico de execução por quantia certa aplicável às empresas estatais que exercem simultaneamente serviço público e atividade econômica, indicando a necessidade de uma revisão do entendimento manifestado pela Corte e sugerindo uma solução mais condizente com o singular regime jurídico das empresas estatais nessa condição, utilizando como entidade paradigma a ECT.

Palavras-chave: desenvolvimento; empresa; serviços públicos; atividade econômica; regime processual de execução.

\section{Abstract}

According to the traditional understanding of the Federal Supreme Court (STF) state enterprises are subject to two procedural regimes of judicial enforcement by certain amount, taking as the criterion of choice -one or the other- the core activity that the entity carries. Thus, if the debtor entity has as primary function providing public services, the procedural prerogatives of the Public Administration are extended to it, enabling the execution of the writ by the regime settled by the articles 730 and 731 of the Civil Procedure Code (CPC), while the state entity that explores economic activity is subject to the common judicial enforcement regime applied to the private enterprises, submitted to the provisions of the Book II of the CPC. However, there are state-owned enterprises in Brazil performing both activities simultaneously, such as the Brazilian Post and Telegraph Company (ECT). It happens that the Supreme Court, in analyzing which legal regime of judicial enforcement is applicable to the ECT, simply described the entity as a provider of public service, which is why the privilege of immunity over property, rents and services was applied, determining the incidence of the scheme of precatory. In this context, this research aims to question the position adopted by the Supreme Court regarding the legal regime of judicial enforcement for certain amount applicable to state enterprises that simultaneously provide public service and explore economic activity, indicating the need for a revision of the understanding shown by the Court and suggesting a more consistent solution with the peculiar legal status of state enterprises in this condition, using as a paradigm the ECT.

Key words: development; company; public services; economic activity; procedural regime of judicial enforcement. 


\section{CONSIDERAÇÕES INICIAIS.}

Tradicionalmente a jurisprudência do Supremo Tribunal Federal (STF) consolidou entendimento segundo o qual as empresas públicas e sociedades de economia mistas estão sujeitas a dois regimes de execução por quantia certa, cuja aplicação - de um ou de outro- baseia-se na modalidade de atividade que a entidade exerce. ${ }^{1}$

Assim, caso a empresa estatal seja exploradora de atividade econômica, estará sujeita ao regime de execução comum às empresas controladas pela iniciativa privada, qual seja, o disposto no Livro II do Código de Processo Civil $(\mathrm{CPC})$, ao passo que as empresas estatais que prestam serviço público têm para si estendidas as prerrogativas processuais da Fazenda Pública, possibilitando a sua execução pelo regime dos precatórios.

No entanto, quando a empresa pública ou sociedade de economia mista exerce ambas as atividades, ou seja, presta serviço público e explora atividade econômica concomitantemente, qual será o regime jurídico aplicável?

O STF já enfrentou um caso que retrata exatamente a controvérsia em análise, no qual se discutiu qual o processo de execução aplicável à Empresa Brasileira de Correios e Telégrafos, cuja ementa segue transcrita abaixo:

RECURSO EXTRAORDINÁRIO. CONSTITUCIONAL. EMPRESA BRASILEIRA DE CORREIOS E TELÉGRAFOS. IMPENHORABILIDADE DE SEUS BENS, RENDAS E SERVIÇOS. RECEPÇÃO DO ARTIGO 12 DO DECRETO-LEI No 509/69. EXECUÇÃO. OBSERVÂNCIA DO REGIME DE PRECATÓRIO. APLICAÇÃO DO ARTIGO 100 DA CONSTITUIÇÃO FEDERAL. 1. À empresa Brasileira de Correios e Telégrafos, pessoa jurídica equiparada à Fazenda Pública, é aplicável o privilégio da impenhorabilidade de seus bens, rendas e serviços. Recepção do artigo 12 do Decreto-lei n 509/69 e não-incidência da restrição contida no artigo $173, \mathbb{S} 1^{\circ}$, da Constituição Federal, que submete a empresa pública, a sociedade de economia mista e outras entidades que explorem atividade econômica ao regime próprio das empresas privadas, inclusive quanto às obrigações trabalhistas e tributárias. 2. Empresa pública que não exerce atividade econômica e presta serviço público da competência da União Federal e por ela mantido. Execução. Observância

BRASIL. SUPREMO TRIBUNAL FEDERAL. 2a Turma. Recurso Extraordinário $\mathrm{n}^{\circ}$. 592.004-AgR. Rel. Min. Joaquim Barbosa. Julgamento em 22.6.2012. Nesse mesmo sentido: BRASIL. SUPREMO TRIBUNAL FEDERAL. 2a Turma. Recurso Extraordinário ${ }^{\circ}$. 698.357-AgR/RS. Min. Cármen Lúcia. Julgamento em 4.10.2012; BRASIL. SUPREMO TRIBUNAL FEDERAL. 2a Turma. Recurso Extraordinário nº 712.648. Min. Cármen Lúcia. Julgamento em 12.10.2012; BRASIL. SUPREMO TRIBUNAL FEDERAL. Recurso Extraordinário $n^{\circ}$.580.264. Min. Ayres Britto, Plenário. Julgamento em 6.10.2011. 
ao regime de precatório, sob pena de vulneração do disposto no artigo 100 da Constituição Federal. Recurso extraordinário conhecido e provido ${ }^{2}$.

No caso em questão, observa-se que o STF afirmou que a Empresa Brasileira de Correios e Telégrafos se classifica como entidade prestadora de serviço público, razão pela qual lhe foi aplicado o privilégio da impenhorabilidade de bens, rendas e serviços, devendo a execução observar o regime de precatório.

Ocorre que a Empresa Brasileira de Correios e Telégrafos representa um caso singular de prestação concomitante de serviço público e exploração de atividade econômica, pois além de a empresa prestar o serviço postal (serviço público), também exerce atividade de logística no transporte de mercadorias (atividade econômica).

Nesse contexto, o presente estudo tem o intuito de questionar o entendimento exarado pelo STF no tocante ao regime jurídico do processo de execução por quantia certa aplicável às empresas estatais que prestam serviço público e exploram atividade econômica, como é o caso da Empresa Brasileira de Correios e Telégrafos, indicando a necessidade de revisão da jurisprudência da Corte e sugerindo solução mais condizente com o singular regime jurídico das entidades em questão.

\section{BREVE HISTÓRICO DAS EMPRESAS ESTATAIS.}

No Brasil as primeiras empresas estatais com fins econômicos remontam às companhias holandesas e portuguesas da época da Coroa, séc. XV e XVI, cujo objetivo era exportar mercadorias para o mercado europeu. Na mesma época, as tapeçarias francesas, bem como os empreendimentos marítimos da Coroa, eram importantes fontes de captação de receita para o cofre real. ${ }^{3}$

Porém, pode-se dizer que o surgimento e consolidação de empresas estatais no Brasil visando à intervenção do Estado no domínio econômico é um episódio mais contemporâneo ${ }^{4}$.

A primeira empresa estatal constituída no País foi o Banco do Brasil, em 1808, mediante a conjunção de capitais públicos e privados. Posteriormente surge o Instituto de Resseguros do Brasil, em 1939; a Companhia Siderúrgica Nacional, em 1941; a Companhia do Valle do Rio Doce e o Banco do Crédito de

2 BRASIL. SUPREMO TRIBUNAL FEDERAL. Tribunal Pleno. Recurso Extraordinário $\mathrm{n}^{\circ}$. RE: 220906 DF. Min. Maurício Corrêa. Julgamento em 16.11.2000.

3 BARROSO, Luís Roberto. "Regime jurídico das empresas estatais". Revista de Direito Administrativo. v. 242, p. 85-93, out./dez. Rio de Janeiro, 2005. p. 85.

$4 \quad$ Ibídem. 
Borracha, em 1942; a Companhia Nacional de Álcalis, em 1943; a Companhia Hidroelétrica do São Francisco, em 1945; a Fábrica Nacional de Motores, em 1946; a Petróleo Brasileiro S. A. (Petrobras), em 1953 e a Centrais Elétricas Brasileiras S.A., em $1961^{5}$.

Grande parte das empresas estatais mencionadas surge com o escopo de fomentar a industrialização do País, pois a iniciativa privada não tinha recursos suficientes para promover o desenvolvimento desse setor. Nesse sentido esclarece Luís Roberto Barroso: "Nos países de industrialização tardia, onde a iniciativa privada era frágil, somente o Estado detinha o capital ou, seu substituto desastrado, a máquina de imprimir dinheiro. Nesse cenário, a atuação econômica e empresarial do Estado tornou-se inevitável como instrumento do desenvolvimento (...)"6.

Com o fortalecimento da indústria nacional, ocorre uma significativa alteração das funções e das finalidades das empresas estatais, que passam à função de prestadoras de serviços públicos e interventoras no domínio econômico ${ }^{7}$.

No passado mais recente, especificamente 1980 e 1990, observa-se nova mudança nesse cenário. Através dos programas de privatização ocorre a paulatina transferência do controle de diversas empresas estatais para a iniciativa privada ${ }^{8}$.

Apesar da onda de privatizações que marcou o Brasil nas últimas décadas, dados do Departamento de Coordenação e Controle de Empresas Estatais (DEST) apontam que em 2007 havia no Brasil 99 estatais no âmbito federal. Desse total, $77,8 \%$ no setor produtivo e 22,2\% no setor financeiro. Em 2007, as empresas estatais federais realizaram investimentos da ordem de $\mathrm{R} \$ 39,8$ bilhões representando uma execução de $74,7 \%$ dos valores previstos no Orçamento de Investimento das empresas estatais para o exercício?.

$5 \quad$ Ibídem. p. 87.

6 BARROSO, Luís Roberto. Estado e livre iniciativa na experiência constitucional brasileira.Migalhas.Disponívelem:<http://www.migalhas.com.br/dePeso/16,MI199284, 71043-Estado+e+livre+iniciativa+na+experiencia+constitucional+brasileira $>$. [Acessado em: 18 Ago.2014].

7 SCHIRATO, Vítor Rhein. "Novas anotações sobre as empresas estatais". Revista de Direito Administrativo. v. 239, p. 209-240, jan./mar. Rio de Janeiro, 2005. p. 209.

8 MIRANDA, Rubens Augusto de, AMARAL, Hudson Fernandes. "Governança corporativa e gestão social responsável em empresas estatais". Revista de Administração Pública. , v. 45, p. 1069-1094, jul./ago. Rio de Janeiro, 2011. p. 1070.

9 BRASIL. MINISTÉRIO DO PLANEJAMENTO, ORÇAMENTO E GESTÃO. Perfil das Empresas Estatais: Exercício de 2007. Brasília: MP/SE/DEST, 2008. p. 13-15. 
Os dados demonstram que ainda é significativa a quantidade de empresas estatais atuantes na economia brasileira, seja prestando serviços públicos, seja explorando atividades econômicas, seja ainda exercendo ambas as atividades.

Por tais razões, mostra-se relevante a análise do regime jurídico de execução por quantia certa das empresas estatais, pois ainda são entidades pujantes que exercem um papel de inestimável importância na economia e na organização do Estado brasileiro.

\section{CONCEITO E FORMA DAS EMPRESAS ESTATAIS.}

A Administração Pública brasileira se divide em duas frentes de atuação, uma chamada Administração Direta, que engloba as pessoas políticas componentes do Estado, dotadas de capacidade legislativa (União, Estados, Municípios e Distrito Federal), e Administração Indireta, composta por entidades públicas (v.g., autarquias) ou privadas (v.g., empresas públicas e sociedades de economia mista) com capacidade administrativa ${ }^{10}$.

O termo empresa estatal ou governamental é utilizado para designar todas as entidades de que o Estado tenha controle acionário, abrangendo no Direito brasileiro três formas: as empresas públicas, as sociedades de economia mista e as demais entidades existentes que vieram a ser adquiridas pelo Poder Público sem autorização específica em lei ou em desacordo com os procedimentos legais para instituição das empresas estatais ${ }^{11}$.

O conceito de empresa pública e de sociedade de economia mista provém do Decreto-Lei no 200, de 25 de Fevereiro de 1967, posteriormente alterado pelo Decreto-Lei $n^{\circ} 900$, de 1969 , que em seu art. $5^{\circ}$ trouxe a seguinte definição:

Art. $5^{\circ}$ Para os fins desta lei, considera-se:(...)

II - Emprêsa Pública - a entidade dotada de personalidade jurídica de direito privado, com patrimônio próprio e capital exclusivo da União, criado por lei para a exploração de atividade econômica que o Govêrno seja levado a exercer por fôrça de contingência ou de conveniência administrativa podendo revestir-se de qualquer das formas admitidas em direito. (Redação dada pelo Decreto-Lei no 900, de 1969)

III - Sociedade de Economia Mista - a entidade dotada de personalidade jurídica de direito privado, criada por lei para a exploração de atividade econômica, sob a forma de sociedade anônima, cujas ações com direito a voto

10 NOHARA, Irene Patrícia. Direito Administrativo. 4ª Ed. São Paulo: Atlas, 2014. p. 545 e ss.

$11 \quad$ SCHIRATO. Op. cit. p. 210. 
pertençam em sua maioria à União ou a entidade da Administração Indireta. (Redação dada pelo Decreto-Lei nº 900, de 1969).

Ocorre que a definição trazida pelo referido Decreto-Lei não reflete o verdadeiro escopo das empresas públicas e sociedades de economia mista na atualidade, vez que os conceitos contidos em referidos termos são equivocados ao afirmarem que as entidades estatais serão constituídas exclusivamente para explorar atividade econômica, excluindo a possibilidade de prestação de serviços públicos. $^{12}$

O melhor conceito capaz de traduzir o significado de empresas públicas e sociedade de economista mista é o que engloba todas as suas possíveis atividades, podendo, desta forma, assim serem definidas:

Empresas públicas são entidades, comerciais ou civis, constituídas pelo Estado sob quaisquer das formas societárias admitidas em Direito Privado (quando concebidas pela União podem ser criadas novas formas societárias ${ }^{13}$ ), mediante a edição de lei autorizadora, com personalidade jurídica de Direito Privado e capital subscrito e integralizado com recursos oriundos exclusivamente do Poder Público, cuja finalidade é o exercício de atividade econômica e/ou prestação de serviço público ${ }^{14}$.

Sociedades de economia são entidades constituídas obrigatoriamente sob o regime de sociedade anônima, cuja criação é autorizada por lei, com personalidade jurídica de Direito Privado e compostas de capitais públicos e privados ou somente capitais públicos de diferentes entes da Administração Pública, cuja finalidade é a exploração de atividade econômica e/ou prestação de serviço público ${ }^{15}$.

Dos conceitos apresentados podem se extrair alguns elementos comuns das empresas estatais: (i) são criadas por lei; (ii) têm vinculação com o Poder Público; (iii) possuem personalidade jurídica; (iv) têm patrimônio próprio e (v) prestarão serviço público ou explorarão atividade econômica.

O primeiro elemento - (i) são criadas por lei - diz respeito as empresas estatais necessitarem de autorização legal para sua constituição. A lei não

12 MELLO, Celso Antônio Bandeira de. Curso de Direito Administrativo. 30. ed. São Paulo: Malheiros, 2013. p. 194; SCHIRATO. Op. cit. p. 210 e 211.

13 Por exemplo a Caixa Econômica Federal, que é organizada sob a forma de sociedade unipessoal, cujo desenho societário foi criado através da própria lei que autorizou sua concepção.

$14 \quad$ SCHIRATO. Op. cit. p. 211.

15 Ibídem. 
cria a empresa, mas tão somente permite sua concepção. Assim sendo, o nascimento de uma empresa pública ou sociedade de economia mista depende do cumprimento de todas as formalidades previstas na legislação de Direto Empresarial, nos moldes de Direito Privado. Deste modo, conforme for a forma societária adotada, será necessário, entre outros atos, o registro do estatuto da empresa na junta comercial para lhe dar vida. ${ }^{16}$ Nesse sentido o art. 37, XIX, da CF dispõe que "somente por lei específica poderá ser criada autarquia e autorizada a instituição de empresa pública, de sociedade de economia mista e de fundação, cabendo à lei complementar, neste último caso, definir as áreas de sua atuação".

No tocante à necessária previsão legislativa para criação das sociedades de economia mista, também dispõe a Lei de Sociedades por Ações (Lei $\mathrm{n}^{\circ}$ 6.404/1976) em seu art. 236 o seguinte comando: "A constituição de companhia de economia mista depende de prévia autorização legislativa”.

Necessariamente as empresas estatais possuem vinculação com o Poder Público, ainda que desfrutem de personalidade jurídica própria, tendo, por exemplo, o dever de prestar contas ao Tribunal de Contas a que se vinculam, a obrigação de licitar, dentre outros. ${ }^{17}$

Quanto à personalidade jurídica, as empresas estatais possuem personalidade própria, desvinculada do ente da administração pública que as criou. Esse é o entendimento da jurisprudência sobre o tema:

AÇÃO DE REINTEGRAÇÃO DE POSSE - IMÓVEL PERTENCENTE À TERRACAP - ILEGITIMIDADE ATIVA DO DISTRITO FEDERAL. 1. Pertencendo o imóvel objeto do pedido reintegratório à terracap, empresa pública dotada de autonomia e personalidade jurídica própria, patente é a ilegitimidade do distrito federal para integrar o pólo ativo da demanda. 2. Recurso do réu provido. Prejudicado o recurso do autor. Decisão unânime ${ }^{18}$.

No que se refere ao patrimônio das empresas estatais, não se trata de bens públicos. Em que pese a origem dos bens utilizados para integralização de parte do capital social das sociedades de economia mista ou para constituição da empresa pública tenham origem em recursos do Poder Público, a partir do momento em que ocorre a alienação do patrimônio público para a entidade

$16 \quad$ NOHARA. Op. cit. p. 605.

17 DI PIETRO, Maria Sylvia Zanella. Direito Administrativo. 25. ed. São Paulo: Atlas. 2012. p. 511.

18 DISTRITO FEDERAL. TRIBUNAL DE JUSTIÇA DO DISTRITO FEDERAL. AC $\mathrm{n}^{\circ}$. 19980110013585 DF. Relator Adelith de Carvalho Lopes. Julgamento em: 25.09.2000. 
privada os bens perdem o vínculo com o patrimônio público e passam a ser de propriedade da instituição estatal privada ${ }^{19}$.

Por fim, o último ponto a ser explorado diz respeito ao tipo de atividade exercitada pela empresa pública ou sociedade de economia mista. Serviço público, de acordo com a definição de autoria de Celso Antônio Bandeira de Mello, consiste em "toda atividade de oferecimento de utilidade ou comodidade material fruível diretamente pelos administrados, prestado pelo Estado ou por quem lhe faça as vezes, sob um regime de Direito Público - portanto consagrador de prerrogativas de supremacia e de restrições especiais -, instituído pelo Estado em favor dos interesses que houve definido como próprio no sistema normativo" ${ }^{20}$.

Conforme se observa, os serviços públicos constituem atividades de grande relevância social, que o Estado assume para si próprio, dado o grau de utilidade e necessidade para a população. Ainda, o jurista arrola seis traços distintivos presentes na atividade de serviço público: “(a) tratar-se de uma prestação de atividade singularmente fruível pelos usuários; b) consistir em atividade material ; (c) destinar-se à satisfação da coletividade em geral; (d) ser reputado pelo Estado como particularmente importante para a satisfação dos interesses sociais; (e) ter sido havida como insuscetível de ser relegada tão só aos empreendimentos da livre iniciativa, razão porque assume como pertinente a si próprio (ainda que nem sempre com exclusividade) e (f) submetê-la a uma específica disciplina de Direito Público"21.

Já o conceito de atividade econômica em sentido estrito pode ser encontrado nas lições de Marçal Justen Filho, que afirma tratar-se de atividade que se caracteriza pela exploração econômica lucrativa, orientada por princípios informantes da atividade empresarial e calcada em uma lógica estritamente econômica. O conceito, segundo o autor, tem como pressuposto o uso da propriedade privada com vistas à promoção de interesses dos particulares, delineando-se, pois, com apoio nos princípios da exploração empresarial, da livre iniciativa e da livre concorrência. A ideia de atividade econômica stricto sensu pressupõe, ademais, que "os sujeitos possam organizar fatores de produção para a obtenção de resultados não predeterminados pelo Estado, com a apropriação privada do

19 GASPARINI, Diógenes. Direito Administrativo. 15. ed. São Paulo: Saraiva. 2010. p. 491 e 504.

$20 \quad$ MELLO, Celso Antônio Bandeira de. Op. cit. p. 687.

21 MELLO, Celso Antônio Bandeira de. Serviço Público e sua feição constitucional no Brasil. In: SALGADO, David Cienfuegos; OLIVEIRA, Miguel Alejandro López (Coord.). Estudios en homenaje a don Jorge Fernández Ruiz: Responsabilidad, contratos y servicios públicos. México: Universidade Nacional Autónoma de México, 2005. p. 5-6. 
lucro"22. Oportuno, porém, lembrar que atividades com estas características podem, por força da Constituição ou de uma lei, passar à categoria de serviços públicos, como sucede com o serviço funerário, com os serviços públicos de energia elétrica, de telefonia e outros.

Dos ensinamentos acima, extrai-se que a atividade econômica em sentido estrito explorada pelo Estado engloba todas as atividades que tenham como resultado o lucro, a movimentação de riqueza (excluindo-se os serviços públicos, conforme ressalvado linhas acima), realizadas pelas em empresas públicas ou sociedade de economia mista em regime de livre concorrência.

A distinção retro apresentada entre as empresas estatais que executam atividade econômica em sentido estrito e aquelas que prestam serviços públicos é de fundamental importância para definição do regime jurídico que incidirá com maior intensidade em cada um desses tipos de empresas estatais, conforme será demonstrado no tópico seguinte.

\section{O REGIME JURÍDICO APLICÁVEL ÀS EMPRESAS}

\section{ESTATAIS.}

A Constituição Brasileira de 1988 impõe em seu art. 173 que, exceto os casos previstos na Constituição, a exploração direta de atividade econômica somente será permitida quando necessária a assegurar a segurança nacional ou relevante interesse coletivo ${ }^{23}$.

Por sua vez, o $\$ 1^{\circ}$ do art. 173 determina que a lei estabelecerá o estatuto jurídico da empresa pública e da sociedade de economia mista que explorem atividade econômica de produção ou comercialização de bens ou de prestação de serviços, devendo ser observada a sujeição dessas entidades ao regime jurídico próprio das empresas privadas, incluindo todas as obrigações inerentes ao regime de Direito Privado, inclusive as de natureza cível, comercial, trabalhista e tributária.

Desse modo, resta claro que as empresas públicas e sociedades de economia mista que exercem atividade econômica devem obedecer, em regra, as normas de Direito Privado. Não obstante existam normas de Direito Público que incidam sobre as empresas estatais, tal como a exigência de licitar (art. 173, $\mathbb{S}$ $1^{\circ}$, III da CF) ou a necessidade de contratação de pessoal através de concurso

22 JUSTEN FILHO, Marçal. O Direito das Agências Reguladoras Independentes. 1. ed. São Paulo: Dialética, 2002. p. 310.

23 ART. 173.-Ressalvados os casos previstos nesta Constituição, a exploração direta de atividade econômica pelo Estado só será permitida quando necessária aos imperativos da segurança nacional ou a relevante interesse coletivo, conforme definidos em lei. 
público (art. 37, II da CF), tratam-se de exceções expressamente definidas pela Constituição e claramente delimitadas na lei ${ }^{24}$.

Considerando-se que a própria Constituição estabelece o regime jurídico de Direito Privado para as empresas estatais exploradoras de atividade econômica, nem sequer a lei ordinária pode prever o contrário, devendo qualquer exceção estar prevista na própria Constituição ainda que implicitamente ${ }^{25}$.

No entanto, na hipótese de a empresa pública ou sociedade de economia mista prestar um serviço público ou uma atividade econômica assumida pelo Estado como serviço público, sofrerá o influxo de princípios e regras de Direito Público. A incursão do Direito Público no caso das estatais prestadoras de serviço público ocorre em razão do disposto no art. 175 da Constituição, segundo o qual é dever do Poder Público, diretamente ou mediante regime de concessão ou permissão, prestar o serviço público. Logo, mesmo as empresas estatais, quando prestadoras de serviços públicos, atuam como concessionárias ou delegatárias, conforme o caso, e dessa forma se submetem à norma do art. 175 da CF, com todas as imposições normativas dela derivadas, tais como o dever de manutenção de serviço público adequado, a submissão ao mesmo regime aplicável ao Estado quanto à responsabilidade patrimonial extracontratual ${ }^{26}$.

Esse fenômeno é explicado por Emerson Gabardo de forma muito clara, ao afirmar que mesmo no âmbito das empresas estatais, existe uma diferenciação em relação ao seu regime jurídico, conforme a atividade por elas exercida: "tratando-se de empresa prestadora de serviços públicos, haverá uma incidência maior dos princípios e regras inerentes ao regime de Direito Público. Cuidando-se, por outro lado, de sociedades empresárias exploradoras de atividades econômicas em sentido estrito, a sua disciplina jurídica contará com um número menos acentuado de imposições próprias de tal regime jurídico, contando com uma afetação maior por normas de Direito Privado ${ }^{27}$."

Nesse sentido, Maria Sylvia Zanella Di Pietro ressalta que quando se está diante de atividade econômica explorada pelo Estado com base no art. 173 da Constituição, que estabelece a incidência do Direito Privado, "este é que se

$24 \quad$ NOHARA. Op. cit. p. 599-600.

25 DI PIETRO. Op. cit. p. 501.

26 MELLO. Curso de Dereito. Op. cit. p. 203.

27 GABARDO, Emerson. O regime jurídico da Empresa Brasileira de Correios e Telégrafos: entre serviço público e atividade econômica em sentido estrito. In: GONÇALVES, Guilherme de Salles, GABARDO, Emerson (Coord.). Direito da Infraestrutura: temas de organização do Estado, serviços públicos e intervenção administrativa. Belo Horizonte: Fórum, 2012. p. 31. 
aplicará, no silêncio da norma publicística; por outras palavras, presume-se a aplicação do regime de direito privado, só derrogado por norma expressa, de interpretação restrita. Quando, porém, o Estado fizer a gestão privada do serviço público, ainda que de natureza comercial ou industrial, aplicam-se, no silêncio da lei, os princípios de direito público, inerentes ao regime jurídico administrativo" 28 .

Cabe observar que a submissão das empresas estatais que exercem atividade econômica ao regime preponderante de Direito Privado visa a atribuir maior flexibilidade ao Estado quando este atua no campo econômico, permitindo o desenvolvimento de suas atividades sem os aspectos burocráticos típicos da Administração Pública que são incompatíveis com a agilidade exigida no mundo dos negócios. ${ }^{29}$ Por outro lado, a aplicação das normas de Direito Privado também visam a igualar o Estado com as demais empresas privadas que atuam no setor, colocando ambas em pé de igualdade em termos concorrenciais, sem que estatais possuam vantagens competitivas em relação às empresas privadas ${ }^{30}$.

A presente distinção ganha relevância em matéria de aplicação e interpretação de leis. Assim, por exemplo, caso uma empresa estatal que presta um serviço público provoque danos a alguém, como regra geral o regime de sua responsabilização patrimonial será o do art. $37, \mathbb{\$} 6^{\circ}$, da Constituição, ao passo que, caso a empresa estatal que explora atividade econômica se envolva em idêntica situação e cause danos a outrem, sua responsabilidade será aquela regida pelo Código Civil ${ }^{31}$.

Feitas essas considerações sobre qual deve ser o influxo de normas, de Direito Público ou Privado, aplicável às empresas estatais, considerando-se a natureza da atividade que prestam, cabe agora tecer as consequências desse fenômeno sobre o regime processual de execução forçada de quantia certa contra essas entidades.

28 DI PIETRO. Op. cit. p. 502.

29 RIBEIRO, Marcia Carla Pereira, TORRES, Paula Ritzmann. "O procedimento licitatório simplificado da Petrobras - O dilema jurisprudencial de uma sociedade estatal de mercado". Revista de Direito Empresarial - RDEemp. Ano 10, n. 1, p. 169-188, jan./abr. Belo Horizonte, 2013. p. 169-172 e 179-184.

30 CARVAlHOSA, Modesto. Comentários à Lei de Sociedades Anônimas. São Paulo: Saraiva. 2011. p. 351.

$31 \quad$ NOHARA. Op. cit. p. 603.

196 Revista del Instituto Colombiano de Derecho Procesal • No. 41 


\section{O REGIME DE EXECUÇÃO POR QUANTIA CERTA INCIDENTE NAS HIPÓTESES QUE ENVOLVEM}

EMPRESAS ESTATAIS.

O processo de execução forçada em relação às empresas públicas e sociedades de economia mista obedece, como regra geral, o regime do Código de Processo Civil. Assim, quando se trata de processo de execução para entrega de coisa, de obrigação de fazer ou não fazer, de busca e apreensão, entre outros, é aplicável às empresas estatais o mesmo regime de execução aplicável aos particulares, qual seja, o conjunto de disposições previsto no Livro II do CPC. ${ }^{32}$ Todavia, existem exceções a essa regra geral, sendo uma delas a do processo de execução por quantia certa.

Na hipótese de a empresa pública ou sociedade de economia mista ser devedora de quantia certa, existem dois regimes distintos de execução que podem ser aplicados: um regulado pelo art. 730 e 731 do CPC e outro pelo regime geral de execução aplicável aos devedores particulares, previsto no Livro II do CPC $^{33}$.

Conforme exposto no item anterior, de acordo com o tipo de atividade exercida pela empresa estatal, se exploração de atividade econômica ou prestação de serviço público, ocorrerá no primeiro caso uma maior influência de normas de Direito Privado e no segundo uma maior incidência das normas de Direito Público.

Nãoédemais lembrar que a aplicação das normas de Direito Privadoàs empresas públicas e sociedade de economia mista que exploram atividade econômica permite que tais empresas se beneficiem da possibilidade de utilização de instrumentos de Direito Privado capazes de desburocratizar o seu funcionamento e otimizar seus resultados, possibilitando a aferição de lucro e concorrência nas mesmas condições de igualdade com a iniciativa privada. ${ }^{34}$ Ocorre que, sendo a empresa estatal constituída sob o regime específico de Direito Empresarial e se beneficiando das técnicas jurídicas próprias das entidades com quem concorre na exploração da atividade econômica, torna-se lógico e necessário que responda no processo executivo por quantia certa do mesmo modo que respondem as demais empresas privadas. Trata-se do corolário de uma concorrência igualitária ${ }^{35}$.

32 GASPARINI. Op. cit. p. 491.

33 THEODORO JÚNIOR, Humberto. "O regime processual da execução das dívidas das empresas estatais”. Revista Síntese Direito Civil e Processual Civil. v. 12, p. 81-94, nov./ dez, 2013. p. 81.

34 RIBEIRO. Op. cit. 169-170.

35 THEODORO JÚNIOR Op. cit. p. 85. 
O Estado tem a liberdade para escolher por qual forma quer desenvolver suas atividades, seja de forma direta ou indireta, através de pessoas jurídicas de natureza pública, como as autarquias, ou as de natureza privada, como as sociedades de economia e empresas públicas. Ao escolher qual modalidade irá utilizar para exercitar suas funções, será obrigado a suportar o respectivo regime jurídico.

Assim, no caso das empresas estatais exploradoras de atividade econômica, em que pese o Estado receber o bônus de exercitar suas atividades de forma menos burocrática e mais dinâmica, terá o ônus de submeter a empresa de cujo capital participa ao regime obrigacional e processual comum, aplicável às pessoas jurídicas de Direito Privado, por força do art. 173, da CF. Tais entidades não podem receber os benefícios conferidos pelos arts. 730 e 731 do CPC, que preveem a inalienabilidade dos bens públicos e o regime de pagamento de dívidas via precatórios. A execução pelo regime do precatório é aplicável aos processos em que litiga o Poder Público em razão da condição de inalienabilidade dos bens públicos (art. 100 e 101 do Código Civil), que são indisponíveis e estão fora do comércio, uma vez que tais bens presumem-se essenciais à regular prestação do serviço público pelo Poder Público ${ }^{36}$.

Necessário, no entanto, lembrar que os bens imprescindíveis para a adequada prestação do serviço público, ainda que adquiridos ou construídos pelo concessionário, são bens reversíveis, ou seja, ao final da concessão revertem ao patrimônio do Poder Concedente e, se ainda não amortizados, o valor correspondente converte-se em indenização.

Os bens públicos, os quais compõem o patrimônio das pessoas jurídicas de Direito Público, são qualificados pelo art. 99 do Código Civil, que aponta o seguinte rol:

ART. 99.- São bens públicos:

I- os de uso comum do povo, tais como rios, mares, estradas, ruas e praças;

II- os de uso especial, tais como edifícios ou terrenos destinados a serviço ou estabelecimento da administração federal, estadual, territorial ou municipal, inclusive os de suas autarquias;

36 Nesse sentido a jurisprudência do Supremo Tribunal Federal: BRASIL. SUPREMO TRIBUNAL FEDERAL. Tribunal Pleno. RE nº 599628 DF. Min. Ayres Britto. Julgamento em 25.05.2011; BRASIL. SUPREMO TRIBUNAL FEDERAL. RE: 592004/AL. Min. Joaquim Barbosa. Julgamento em 22.02.2010. Também defende esse posicionamento Humberto Theodoro Júnior (THEODORO JÚNIOR. Op. cit. p. 88), Diógenes Gasparini (GASPARINI. Op. cit. p. 491) e Vítor Rhein Schirato (SCHIRATO. Op. cit. p. 210). 
III- os dominicais, que constituem o patrimônio das pessoas jurídicas de direito público, como objeto de direito pessoal, ou real, de cada uma dessas entidades.

Por seu turno, o art. 98 do Código Civil prevê expressamente que "São públicos os bens do domínio nacional pertencentes às pessoas jurídicas de Direito Público interno; todos os outros são particulares, seja qual for a pessoa a que pertencerem".

Desse modo, considerando-se que as empresas estatais exploradoras de atividade econômica são pessoas jurídicas que se submetem ao regime de Direito Privado, conforme já foi dito exaustivamente, cabe concluir que os bens que compõem o patrimônio dessas empresas não podem ser qualificáveis como bens públicos $^{37}$.

Portanto os bens pertencentes às empresas públicas e às sociedades de economia mista exploradoras de atividade econômica são bens particulares, pelo que tais entidades podem suportar a penhora e expropriação no processo judicial de execução por quantia certa ${ }^{38}$.

Ademais, cabe observar que, ainda que originalmente a formação do capital social das empresas estatais seja composta por bens e recursos públicos, ${ }^{39}$ uma vez constituídas tais entidades elas gozam de personalidade jurídica e patrimônio próprios $^{40}$.

Para a constituição de qualquer empresa, o sócio instituidor transfere seu patrimônio particular para a pessoa jurídica, a qual passa a ser legitima detentora do bem, ao passo que a pessoa física recebe em troca do valor investido quotas sociais, que podem lhe outorgar, por exemplo, poderes de voto e direito de receber dividendos. Nesse sentido, esclarece Humberto Theodoro Júnior que o capital social, após ser integralizado, "integra o patrimônio autônomo da pessoa jurídica, deixando os bens e valores assim investidos de ser algo pertencente ao investidor. Desde então, o sócio ou investidor passa a ter direitos correspondentes à cota de participação social, mas não mais os bens com que ela se integralizou" ${ }^{41}$.

37 THEODORO JÚNIOR. Op. cit., pp. 85-87.

38 Ibídem.

$39 \quad$ NOHARA. Op. cit. pp. 606-607.

40 Nesse sentido, cabe citar os seguintes julgados: BRASIL. SUPERIOR TRIBUNAL DE JUSTIÇA. $1^{\circ}$ Turma. REsp: 879999 MA. Ministro Luiz Fux. Julgamento em 02.09.2008; BRASIL. TRIBUNAL REGIONAL FEDERAL DA 1 $1^{\text {a }}$ REGIÃO. $4^{\text {a }}$ Turma Suplementar. AC nº 22124 BA. Relator Márcio Barbosa Maia. Julgamento em 31.07.2012. DISTRITO FEDERAL. TRIBUNAL DE JUSTIÇA DO DISTRITO Federal. 3a Turma Cível AC: 3627695 DF. Relatora Nancy Andrighi. Julgamento em 18.12.1995.

$41 \quad$ THEODORO JÚNIOR. Op. cit. p. 87. 
Assim sendo, é possível concluir que não é relevante a origem do capital social das empresas estatais provir de bens públicos. Uma vez alienado o patrimônio público para as empresas públicas ou sociedades de economia mista no ato da sua instituição, o bem adquirido legalmente para nova entidade torna-se particular e perde o condão que outrora detinha com o patrimônio público ${ }^{42}$.

Por outro lado, o mesmo não acontece com as empresas estatais quando se dedicam à prestação de serviços públicos. Nesse caso, as entidades são equiparadas à Fazenda Pública, pelo que seu patrimônio fica blindado com as prerrogativas dos bens públicos, tal como impenhorabilidade, inalienabilidade, imprescritibilidade, etc. ${ }^{43}$

Uma das justificativas apresentadas para esse posicionamento é o fato de que as empresas estatais prestadoras de serviço público estão vinculadas ao regime de Direito Público, logo, atraem para si as normas relativas ao processo de execução contra a Fazenda Pública ${ }^{44}$.

Ademais, determinados princípios inerentes à prestação de serviços públicos, como exemplo o princípio da continuidade do serviço público e das atividades administrativas, são incompatíveis com o regime comum de execução, pois eventual afetação dos bens da empresa estatal poderia comprometer o seu desempenho na prestação do serviço público ${ }^{45}$.

Discorrendo sobre o tema Humberto Theodoro Júnior chega a idêntica conclusão, sustentando que às empresas estatais criadas para a exploração de atividades econômicas em sentido estrita não é aplicável a "execução especial dos arts. 730 e 731, devendo seus débitos serem exigidos em juízo no regime comum, ou seja, no regime de penhora e expropriação aplicável a qualquer devedor,

42 GASPARINI. Op. cit. p. 491.

43 Nesse sentido é reiterada e uníssona a jurisprudência do Supremo Tribunal de Justiça, a saber: BRASIL. SUPREMO TRIBUNAL FEDERAL. ACO/RN nº 959. Min. Menezes Direito. Julgamento em 16.05.2008; BRASIL. SUPREMO TRIBUNAL FEDERAL. ACO $\mathrm{n}^{\circ}$. 1095. Min. Ellen Gracie. Julgamento em 02.05.2008; BRASIL. SUPREMO TRIBUNAL FEDERAL. AC/MC/DF n. 1947. Min. Carlos Britto. Julgamento em 21.02.2008; BRASIL. SUPREMO TRIBUNAL FEDERAL. Primeira Turma. AI-AgR nº. 243250/RS. Min. Sepúlveda Pertence. Julgamento em 23.04/2004. De igual modo no Superior Tribunal de Justiça: BRASIL. SUPERIOR TRIBUNAL DE JUSTIÇA. Segunda Turma. REsp: 729807 RJ. Min. Mauro Campbell Marques. Julgamento em 03.11.2009. Na doutrina, advogam tal posição Irene Patrícia Nohara (NOHARA. Op. cit. p. 603-604); Diógenes Gasparini (GASPARINI. Op. cit. p. 508) e Maria Sylvia Zanella Di Pietro (DI PIETRO. Op. cit. p. 519).

44 BRASIL. SUPERIOR TRIBUNAL DE JUSTIÇA. Segunda Turma. REsp: 1086745 SE. Min. Castro Meira,. Julgamento em 14.04.2009.

SCHIRATO. Op. cit. p. 235. 
segundo o Livro II do Código de Processo Civil"; contudo, "permanecem, de outro lado, sujeitas ao regime especial dos arts. 730 e 731 as empresas públicas e sociedades de economia mista instituídas (...) para prestar serviços públicos da competência da União Federal" ${ }^{46}$.

De todo o exposto, é possível concluir em apertada síntese que as empresas públicas e sociedades de economia mista prestadoras de serviço público se submetem ao regime de execução por quantia certa instituído pelos arts. 730 e 731 do CPC, ao passo que as mesmas entidades, quando exploradoras de atividade econômica, estão sujeitas ao regime comum de penhora e expropriação previsto no Livro II do CPC.

No entanto, feitas essas considerações, cabe agora buscar a resposta para a indagação que a presente pesquisa se propôs enfrentar: no caso de a empresa pública ou sociedade de economia mista exercer ambas as funções, ou seja, prestar serviços públicos concomitantemente com a exploração de atividade econômica, qual será o regime jurídico de execução por quantia certa que será aplicável? A presente questão será analisada e respondida com base na situação jurídica da Empresa Brasileira de Correios e Telégrafos, a seguir apresentada.

\section{O REGIME DE EXECUÇÃO CABÍVEL À EMPRESA BRASILEIRA DE CORREIOS E TELÉGRAFOS.}

A Empresa Brasileira de Correios e Telégrafos (ECT) foi criada por meio do Decreto-Lei no 509/69, que transformou o Departamento dos Correios e Telégrafos em uma empresa pública e lhe conferiu a personalidade jurídica de Direito Privado. A referida norma traçou como objetivo para a empresa em questão aprimorar a execução e o controle, em regime de monopólio, dos serviços postais em todo território nacional.

Segundo dispõe a Lei Federal $n^{\circ}$ 6.538/1978, que estabelece normas sobre os serviços postais, podem ser qualificados como serviços postais os seguintes:

ART. $7^{\circ}$ - Constitui serviço postal o recebimento, expedição, transporte e entrega de objetos de correspondência, valores e encomendas, conforme definido em regulamento.

$\mathbb{S} 1^{\circ}$ - São objetos de correspondência: a) carta; b) cartão-postal; c) impresso; d) cecograma; e) pequena - encomenda.

$\mathbb{} 2^{\circ}$ - Constitui serviço postal relativo a valores: a) remessa de dinheiro através de carta com valor declarado; b) remessa de ordem de pagamento por

46 THEODORO JÚNIOR. Op. cit. p. 88. 
meio de vale-postal; c) recebimento de tributos, prestações, contribuições e obrigações pagáveis à vista, por via postal.

$\$ 3^{\circ}$ - Constitui serviço postal relativo a encomendas a remessa e entrega de objetos, com ou sem valor mercantil, por via postal.

Ocorre que, o objeto social da ECT não se resume à prestação de serviços postais. De acordo com o Decreto $\mathrm{n}^{\circ}$. 83.726/79, também cabe à empresa "explorar atividades correlatas", dentre elas, inclusive, atividades de natureza econômica, tais como os serviços de logística integrada, atualmente exercidos pela empresa estatal.

Assim sendo, chega-se à inevitável conclusão que a ECT presta serviço público quando realiza típicas atividades de natureza postal, porém, de igual modo, explora atividade econômica quando exerce atividades relacionadas à logística integrada.

Sobre o tema cabe trazer à presente pesquisa as importantes considerações de Emerson Gabardo, ao pontuar que "diferentemente dos 'serviços postais', cuja prestação é forçosamente da União por força da Constituição Federal, que a reconhece implicitamente como um serviço público, os 'serviços de logística integrada' não se enquadram em tal categoria, por lhes faltar os elementos material e formal, referidos por Marçal Justen Filho como essenciais à caracterização de uma atividade como serviço público" ${ }^{47}$.

Desse modo, ao explorar a atividade econômica de logística integrada, a ECT se subordina às regras do regime jurídico de Direito Privado e, por consequência, deve suportar a incidência do regime de execução comum na cobrança de seus débitos. Nesse sentido, cabe trazer novamente as lições de Emerson Gabardo, quanto observa que "revelando-se como exercício de atividade econômica em sentido estrito, cumpre reconhecer que os chamados 'serviços de logística integrada, financeiros e eletrônicos' a serem desempenhados pela ECT subordinam-se ao regime jurídico de Direito Privado, afastando-se das amarras jurídicas impostas à atividade de serviço público" ${ }^{48}$.

Assim sendo, considerando a reconhecida natureza híbrida das atividades desenvolvidas pela ECT, propõe-se que seja aplicado a entidade o regime de execução por quantia certa com base no Livro II do CPC, ou seja, com possibilidade de penhora e expropriação de seus bens, porém com certas restrições causadas pela incidência de normas de Direito Público (tal como o princípio da continuidade), sendo permitido, dessa forma, a penhora e expropriação apenas dos bens que não estiverem afetados à consecução da atividade-fim de serviço

\footnotetext{
$47 \quad$ GABARDO. Op. cit. p. 35.

$48 \quad$ Ibídem. p. 36.
} 
postal (serviço público) ou se, ainda que afetados, a penhora não comprometer o desempenho dessa atividade.

Inclusive, a solução que ora se propõe encontra amparo na própria jurisprudência do Superior Tribunal de Justiça (STJ), que em reiterados julgados vem admitindo a penhora de bens de empresas públicas prestadoras de serviço público quando esses bens não comprometam ou não estejam vinculados à atividade-fim da entidade, como se depreende das seguintes ementas:

TRIBUTÁRIO. AGRAVO REGIMENTAL. EXECUÇÃO FISCAL. PÓLO PASSIVO OCUPADO POR CONCESSIONÁRIA DE SERVIÇO PÚBLICO. PENHORA DE IMÓVEIS. SUBSTITUIÇÃO DE IMÓVEIS POR VEÍCULOS. IMPOSSIBILIDADE. RAZOABILIDADE. ART. 678 DO CPC. 1. A aplicação dos arts. 10, 11 e 15 da Lei n. 6.830/80 e 656 do CPC deve ser feita com razoabilidade, especialmente quando está em jogo a consecução do interesse público primário (transporte), incidindo na espécie o art. 678 do CPC. 2. Por isso, esta Corte Superior vem admitindo a penhora de bens de empresas públicas (em sentido lato) prestadoras de serviço público apenas se estes não estiverem afetados à consecução da atividade-fim (serviço público) ou se, ainda que afetados, a penhora não comprometer o desempenho da atividade. Essa lógica se aplica às empresas privadas que sejam concessionárias ou permissionárias de serviços públicos (como ocorre no caso). Precedentes. (... $)^{49}$

PROCESSUAL CIVIL. PENHORA. BENS DE SOCIEDADE DE ECONOMIA MISTA. POSSIBILIDADE. 1. A sociedade de economia mista, posto consubstanciar personalidade jurídica de direito privado, sujeita-se, na cobrança de seus débitos ao regime comum das sociedades em geral, nada importando o fato de prestarem serviço público, desde que a execução da função não reste comprometida pela constrição. Precedentes ${ }^{50}$.

Com base nos julgados acima colacionados, pode-se concluir que, em razão de a ECT concentrar prestação de serviço público e exploração de atividade econômica, cabe a aplicação do regime de execução por quantia certa de "natureza híbrida", sendo, como regra geral, aplicável o regime de execução comum às empresas controladas pelo setor privado, porém com restrições à penhora de bens que comprometam ou prejudiquem a atividade-fim da entidade relacionada à prestação do serviço público de serviços postais.

49 BRASIL. SUPERIOR TRIBUNAL DE JUSTIÇA. Segunda Turma. AgRg no REsp: 1070735 RS. Min. Mauro Campbell Marques. Julgamento em 18.11.2008.

50 BRASIL. SUPERIOR TRIBUNAL DE JUSTIÇA. Primeira Turma. REsp 521.047/SP. Min. Luiz Fux. Julgamento em 16.2.2004; Nesse mesmo sentido: BRASIL. Superior Tribunal de Justiça. Terceira Turma. REsp 343.968/SP. Min. Nancy Andrighi. Julgamento em 4.3.2002 
O caso específico da ECT serve apenas para contextualizar e demonstrar as bases lógicas da aplicação do regime de execução de "natureza híbrida". O regime jurídico em questão deve ser aplicado em todas as ações envolvendo a execução por quantia certa em que figurem como devedoras empresas estatais que prestem serviços públicos simultaneamente com a exploração de atividade econômica.

\section{CONCLUSÃO.}

Pelo exposto, conclui-se que as empresas públicas e sociedades de economia mista prestadoras de serviço público se submetem ao regime de execução por quantia certa pelo regime dos arts. 730 e 731, do CPC, ao passo que as mesmas entidades, quando exploradoras de atividade econômica, estão sujeitas ao regime comum de penhora e expropriação previsto no Livro II do CPC.

No entanto, quando a empresa pública ou sociedade de economia mista exercita ambas as atividades, ou seja, presta serviço público e explora atividade econômica concomitantemente, como é o caso Empresa Brasileira de Correios e Telégrafos, deverá ser aplicável como regra geral o regime de execução comum às empresas controladas pelo setor privado, porém com restrições à penhora de bens que comprometam ou prejudiquem a continuidade, a regularidade, a prestação adequada do serviço público, conforme estabelece o art. $6^{\circ}$ da Lei $8987 / 95$.

\section{REFERÊNCIAS.}

BARROSO, Luís Roberto. Estado e livre iniciativa na experiência constitucional brasileira. Migalhas. Disponível em: <http://www.migalhas.com.br/dePeso/16,MI199284,71043-Estado+e+livre+iniciativa+na+experiencia+constitucional+brasileira $>$. [Acessado em: 18 Ago. 2014].

"Regime jurídico das empresas estatais". Revista de Direito Administrativo. v. 242, p. 85-93, out./dez. Rio de Janeiro, 2005.

CARVAlHOSA, Modesto. Comentários à Lei de Sociedades Anônimas. São Paulo: Saraiva. 2011.

HACHEM, Daniel Wunder. "Direito fundamental ao serviço público adequado e capacidade econômica do cidadão: repensando a universalidade do acesso à luz da igualdade material". AEC - Revista de Direito Administrativo E Constitucional. Ano 14, n. 55, p. 123-158, jan./mar. Belo Horizonte, 2014.

DI PIETRO, Maria Sylvia Zanella. Direito Administrativo. 25. ed. São Paulo: Atlas. 2012.

GABARDO, Emerson. "O regime jurídico da Empresa Brasileira de Correios e Telégrafos: entre serviço público e atividade econômica em sentido estrito”. In: GONÇALVES, Guilherme de Salles; GABARDO, Emerson (Coord.). Direito da Infraestrutura: temas de organização do Estado, serviços públicos e intervenção administrativa. Belo Horizonte: Fórum, 2012. 
GASPARINI, Diógenes. Direito Administrativo. 15. ed. São Paulo: Saraiva, 2010.

JUSTEN FILHO, Marçal. O Direito das Agências Reguladoras Independentes. 1. ed. São Paulo: Dialética. 2002.

MELLO, Celso Antônio Bandeira de. Curso de Direito Administrativo. 30. ed. São Paulo: Malheiros, 2013.

...-..-- "Serviço público e sua feição constitucional no Brasil". In: SALGADO, David Cienfuegos; OLIVEIRA, Miguel Alejandro López (Coord.). Estudios en homenaje a don Jorge Fernández Ruiz: Responsabilidad, contratos y servicios públicos. México: Universidade Nacional Autónoma de México, 2005.

MIRANDA, Rubens Augusto de, AMARAL, Hudson Fernandes. "Governança corporativa e gestão social responsável em empresas estatais”. Revista de Administração Pública. v. 45, p. 1069-1094, jul./ago. Rio de Janeiro, 2011.

NOHARA, Irene Patrícia. Direito Administrativo. 4. ed. São Paulo: Atlas, 2014.

RIBEIRO, Marcia Carla Pereira, TORRES, Paula Ritzmann. "O procedimento licitatório simplificado da Petrobras - O dilema jurisprudencial de uma sociedade estatal de mercado". Revista de Direito Empresarial - RDEemp. Ano 10, n. 1, p. 169-188, jan./abr. Belo Horizonte, 2013.

SCHIRATO, Vítor Rhein. "Novas anotações sobre as empresas estatais". Revista de Direito Administrativo. v. 239, p. 209-240, jan./mar. Rio de Janeiro, 2005.

THEODORO JÚNIOR, Humberto. "O regime processual da execução das dívidas das empresas estatais”. Revista Síntese Direito Civil e Processual Civil. v. 12, p. 81-94, nov./dez. 2013.

\section{JURISPRUDÊNCIA}

BRASIL. MINISTÉRIO DO PLANEJAMENTO, ORÇAMENTO E GESTÃO. Perfil das Empresas Estatais: Exercício de 2007. Brasília: MP/SE/DEST, 2008.

BRASIL. SUPERIOR TRIBUNAL DE JUSTIÇA. $1^{\circ}$ Turma. REsp: 879999 MA. Ministro Luiz Fux. Julgamento em 02.09.2008.

BRASIL. SUPERIOR TRIBUNAL DE JUSTIÇA. Primeira Turma. REsp 521.047/SP. Min. Luiz Fux. Julgamento em 16.2.2004.

BRASIL. SUPERIOR TRIBUNAL DE JUSTIÇA. Segunda Turma. REsp: 1086745 SE. Min. Castro Meira,. Julgamento em 14.04.2009.

BRASIL. SUPERIOR TRIBUNAL DE JUSTIÇA. Segunda Turma. AgRg no REsp: 1070735 RS. Min. Mauro Campbell Marques. Julgamento em 18.11.2008.

BRASIL. SUPERIOR TRIBUNAL DE JUSTIÇA. Segunda Turma. REsp: 729807 RJ. Min. Mauro Campbell Marques. Julgamento em 03.11.2009.

BRASIL. SUPERIOR TRIBUNAL DE JUSTIÇA. Terceira Turma. REsp 343.968/SP. Min. Nancy Andrighi. Julgamento em 4.3.2002.

BRASIL. SUPREMO TRIBUNAL FEDERAL. 2a Turma. Recurso Extraordinário $\mathrm{n}^{\circ}$. 592.004-AgR. Rel. Min. Joaquim Barbosa. Julgamento em 22.6.2012.

BRASIL. SUPREMO TRIBUNAL FEDERAL. 2a Turma. Recurso Extraordinário $\mathrm{n}^{\circ}$. 698.357-AgR/RS. Min. Cármen Lúcia. Julgamento em 4.10.2012. 
BRASIL. SUPREMO TRIBUNAL FEDERAL. 2a Turma. Recurso Extraordinário $\mathrm{n}^{\circ}$. 712.648. Min. Cármen Lúcia. Julgamento em 12.10.2012.

BRASIL. SUPREMO TRIBUNAL FEDERAL. AC/MC/DF n. 1947. Min. Carlos Britto. Julgamento em 21.02.2008.

BRASIL. SUPREMO TRIBUNAL FEDERAL. ACO nº 1095. Min. Ellen Gracie. Julgamento em 02.05.2008.

BRASIL. SUPREMO TRIBUNAL FEDERAL. ACO/RN n. 959. Min. Menezes Direito. Julgamento em 16.05.2008.

BRASIL. SUPREMO TRIBUNAL FEDERAL. PRIMEIRA TURMA. AI-AgR nº. 243250/ RS. Min. Sepúlveda Pertence. Julgamento em 23.04/2004.

BRASIL. SUPREMO TRIBUNAL FEDERAL. RE: 592004/AL. Min. Joaquim Barbosa. Julgamento em 22.02.2010.

BRASIL. SUPREMO TRIBUNAL FEDERAL. Recurso Extraordinário n. 580.264. Min. Ayres Britto, Plenário. Julgamento em 6.10.2011.

BRASIL. SUPREMO TRIBUNAL FEDERAL. Tribunal Pleno. RE nº 599628 DF. Min. Ayres Britto. Julgamento em 25.05.2011.

BRASIL. SUPREMO TRIBUNAL FEDERAL. Tribunal Pleno. Recurso Extraordinário n RE: 220906 DF. Min. Maurício Corrêa. Julgamento em 16.11.2000.

BRASIL. TRIBUNAL REGIONAL FEDERAL DA $1^{\text {a }}$ REGIÃO. $4^{\mathrm{a}}$ Turma Suplementar. AC $\mathrm{n}^{\circ}$. 22124 BA. Relator Márcio Barbosa Maia. Julgamento em 31.07.2012.

DISTRITO FEDERAL. TRIBUNAL DE JUSTIÇA DO DISTRITO FEDERAL. $3^{\text {a } T u r m a ~}$ Cível AC: 3627695 DF. Relatora Nancy Andrighi. Julgamento em 18.12.1995.

DISTRITO FEDERAL. TRIBUNAL DE JUSTIÇA DO DISTRITO FEDERAL. AC n. 19980110013585 DF. Relator Adelith de Carvalho Lopes. Julgamento em 25.09.2000. 